\title{
Fruit and seed biomineralization and its effect on preservation
}

\author{
Erwan Messager • Aïcha Badou • François Fröhlich • \\ Brigitte Deniaux • David Lordkipanidze • \\ Pierre Voinchet
}

Received: 8 October 2009 / Accepted: 26 January 2010/Published online: 13 March 2010

(C) Springer-Verlag 2010

\begin{abstract}
Mineralised fruits and seeds are frequently found in archaeological sediments but their chemical nature has not been often examined. The nature and the origin of these archaeobotanical remains have to be investigated to understand their taphonomic history. Fruits or seeds can be mineralised not only by replacement mineralisation but also by biomineralisation during the plant life. The mineral components of three fossil fruits sampled on the Pleistocene site of Dmanisi were analysed and compared with their modern analogues. Analyses were carried out by means of an environmental scanning electron microscope, equipped with an energy dispersive X-ray device and by means of a Fourier transform infrared spectrometer. Biogenic carbonates and/or biogenic silica were identified in the fossil and modern fruits of some taxa. Comparison between fossil and modern specimens has shown that molecular reorganisation occurred in carbonate and in biogenic silica during
\end{abstract}

\section{E. Messager}

Maison de l'Archéologie et de l'Ethnologie,

UMR 7041, ArscAn, 21, allée de l'Université,

92023 Nanterre cedex, France

E. Messager $(\bowtie) \cdot B$. Deniaux $\cdot$ P. Voinchet

Département de Préhistoire, Muséum national d'Histoire naturelle,

UMR 7194, IPH, 1, rue René Panhard,

75013 Paris, France

e-mail: erwan.m@mnhn.fr

\section{A. Badou $\cdot$ F. Fröhlich}

Département de Préhistoire, Muséum national d'Histoire naturelle, UMR 7194, Centre de Spectroscopie Infrarouge, CP 57, 57, rue Cuvier,

75231 Paris cedex 05, France

D. Lordkipanidze

Georgian National Museum,

3, Rustaveli Avenue,

0105 Tbilisi, Georgia fossilisation, through diagenetic processes. The resulting stable mineral structures confer an exceptional preservation to fruits in sediments. Taking into account these taphonomic specificities (transformation and differential preservation), the chronological and palaeoenvironmental aspects of the mineralised fruits are discussed.

Keywords Fruit remains · Biomineralisation - Taphonomy X-ray EDS · Scanning electronic environmental microscopy $\cdot$ Fourier transform infrared spectroscopy

\section{Introduction}

Plant macroremains recovered from archaeological sites are most commonly charred (e.g. fruits, seeds and wood charcoals), which preserves them from decomposition by micro-organisms in various kinds of deposits. However, mineralised botanical remains (Green 1979) often appear in global charred assemblages and do not seem to be linked with the archaeological context, which makes them difficult to be used by archaeobotanists (van Zeist and Buitenhuis 1983; van Zeist and de Roller 1995). Their occurrence in various contexts and stages of preservation raises questions about their origin and taphonomy (McCobb et al. 2001, 2003). Mineralised archaeobotanical remains can be classified into two groups depending of the nature of mineralisation. The first group, recovered in geological and archaeological deposits (respectively, Wilby and Briggs 1997; McCobb et al. 2001, 2003), has been impregnated with mineral solution. The organic structures have been replaced or replicated and the plant tissues hardened, especially by phosphatisation (Green 1979). The second group corresponds to fossils that have been preserved because some living plants have the capacity to produce 


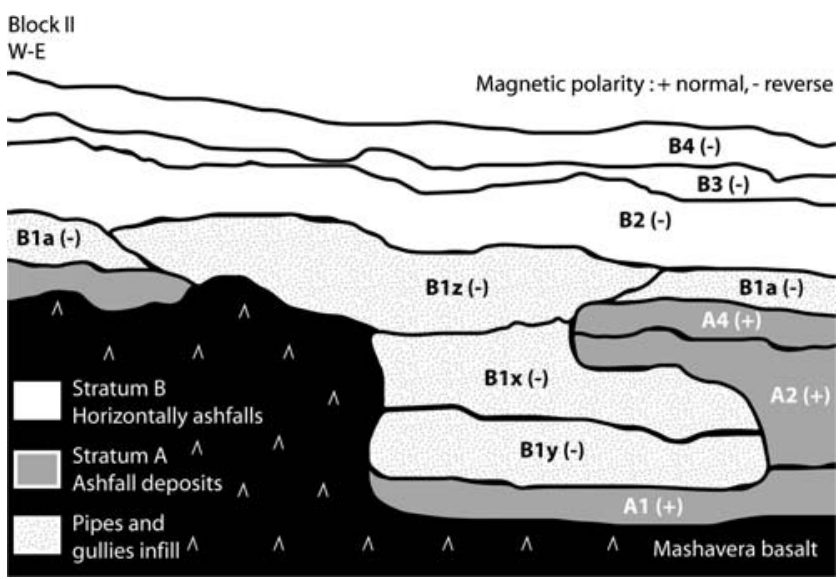

Fig. 1 Stratigraphic interpretations made in Block II. Section $(W-E)$ is $10 \mathrm{~m}$ long, with ca. $1.8 \times$ vertical exaggeration (modified from Lordkipanidze et al. 2007)

mineral matter, i.e., biomineralisation processes in organisms before deposition and burial. Carbonates are most commonly involved in such mineralisation, along with silica (Wang et al. 1997; Jahren et al. 1998, 2001; Pustovoytov et al. 2004; Pustovoytov and Riehl 2006). As mineralised fruits or seeds are commonly collected in archaeological sites or natural deposits, their specific preservation status has to be taken into account and studied. Their detailed analysis is essential for understanding their exact composition and fossilisation to investigate one of the taphonomic features: preservation.

\section{Materials and methods}

\section{Materials}

The fruits analysed in this study comprise fossil fruits and their closest modern analogues. The fossil assemblage comes from the Dmanisi site located in the Lesser Caucasus (Georgia). At the present time, this site is considered as one of the oldest palaeoanthropological sites in Eurasia, with an age close to 1.7 million years. It corresponds to one of the first human dispersal waves out of Africa (Dzaparidze et al. 1989; Gabunia et al. 2000a; Vekua et al. 2002; Lordkipanidze et al. 2007). The sequence at Dmanisi has been divided into two main stratigraphic units: stratum A and stratum B. Piping and gullying of stratum A deposits occurred at the initiation of stratum B deposition (Ferring et al. 2008). Rapid burial by low energy slope processes led to the excellent stratification and preservation of bones in pipe-gully facies, which contain all of the hominin remains. A diagenetic laminar carbonate horizon occurs across the site and helps to preserve faunal and hominin remains which underlie this horizon. The carpological assemblage was collected mainly by sieving, although some remains were recovered during excavation. As with other archaeological remains from the site, almost all fruits come from the several stratum B deposits (Fig. 1). All these mineralised remains were identified by means of ESEM and were classified into eight different groups (Messager et al., 2008). Among these groups, three taxa (Fig. 2) were selected for this study because fragments were available for chemical analysis: fruits of Celtis cf. tournefortii, a small tree of the Ulmaceae family and fruits of Lycopsis cf. orientalis and Buglossoides type arvensis/sibthorpiana, herbaceous plants of the Boraginaceae family.

To identify the fossil remains from the Dmanisi site, a modern fruit reference collection was augmented with specimens from the Herbarium of the 'Museum national d'Histoire naturelle' in Paris and fruits collected during fieldwork in Caucasus. For this study, modern analogues of the three fossil morphotypes (Fig. 2) in the collection were selected from available material of: Celtis sp. L., $L$. orientalis L., B. arvensis L. (mix of B. arvensis subsp. sibthorpiana and $B$. arvensis subsp. tenuiflora). Fossil and modern fruits were cleaned with distilled water and only the mineralised coats were used for analysis.

\section{Methods}

Environmental scanning electronic microscopy and energy dispersive $X$-ray analysis

Fruit observation and composition measurements were made by means of a Philips XL 30 environmental scanning electron microscope (ESEM). Unlike standard electron microscopes, this equipment allows objects to be examined in the ESEM chamber without the need for gold or carbon coating (Deniaux 2002). The samples were first mounted
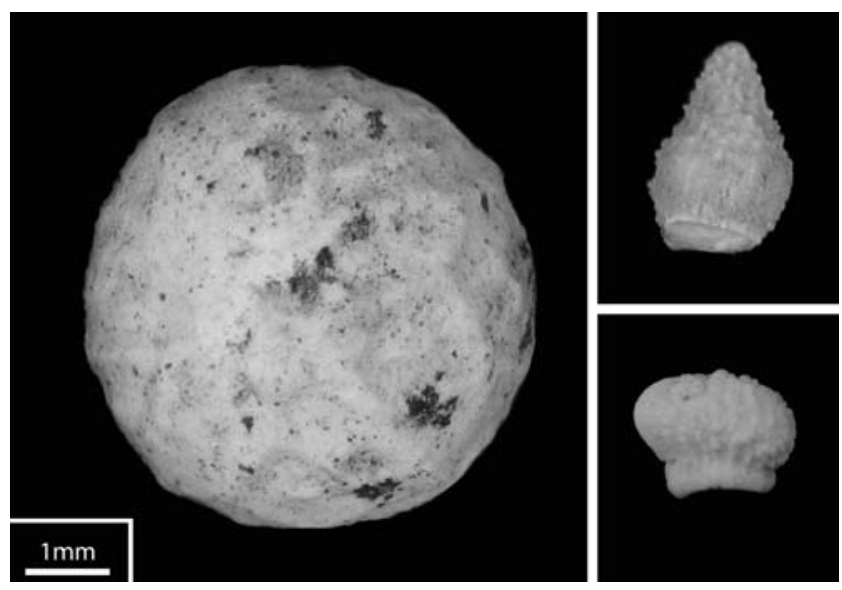

Fig. 2 The three studied fruit morphotypes: Celtis cf. tournefortii (left), Buglossoides type arvensis/sibhtorpiana (top right) and Lycopsis cf. orientalis (bottom right) 
on stubs using carbon double-sided adhesive tape and then introduced into the chamber.

We conducted energy dispersive X-ray (EDX) measurements to identify the elemental composition of the fruit coat from the three taxa groups described above. In EDX, the X-ray detector measures the number of emitted X-rays as a function of their energy. Since elements have a characteristic energy, the EDX spectrum can be used to identify them and to give semi-quantitative results. The energy dispersive X-ray detector of the Philips XL 30 ESEM was used for these analyses.

\section{Fourier transform infrared spectroscopy}

Fourier transform infrared spectroscopy (FTIR) quantitative analyses were performed using the $\mathrm{KBr}$ pellet standard method (Pichard and Fröhlich 1986; Fröhlich 1989; Fröhlich and Gendron-Badou 2002). Samples were first mechanically ground down to a size smaller than the shortest wavelength used $(2.5 \mu \mathrm{m})$, before mixing with $\mathrm{KBr}(0.25 \%$ standard dilution). A pellet (300 $\mathrm{mg}, 13 \mathrm{~mm}$ in diameter) is obtained by compressing the mixture under vacuum. The pellets are dried at $110^{\circ} \mathrm{C}$ in order to remove absorbed water and then analysed with a Brüker Vector 22 FTIR spectrometer (32 scans $-2 \mathrm{~cm}^{-1}$ resolution) in the $4,000-370 \mathrm{~cm}^{-1}$ range (Fröhlich and Gendron-Badou 2002; Gendron-Badou et al. 2003). Quantitative analyses were performed with reference to the mineralogical infrared standard data bank (Centre de Spectroscopie Infrarouge-MNHN).

The FTIR measurement yields indications about fruit coat composition. In this study, this method permits characterisation of the carbonate and silica components involved in fruit mineralisation and to compute the percentage of each present.

\section{Results}

Celtis-type (Ulmaceae)

\section{EDX analysis}

EDX spectra (Fig. 3) of the fossil Celtis fruit show the prevalence of carbon, oxygen and calcium elements. Silica is also recorded. This suggests that carbonate $\left(\mathrm{CaCO}_{3}\right)$, and most probably silica is involved in Celtis coat structure, but part of these components may be due to sediment residues.

\section{FTIR analysis}

\section{a. Fossil Celtis-type}

The IR spectrum of fossil Celtis fruit (Fig. 4) shows only two minerals, calcite $(79 \%)$ and aragonite $(15 \%)$. Organic matter and quartz are present as traces. Quartz is probably due to contamination.
Fig. 3 Surface of fossil Celtis fruits and corresponding EDX spectra

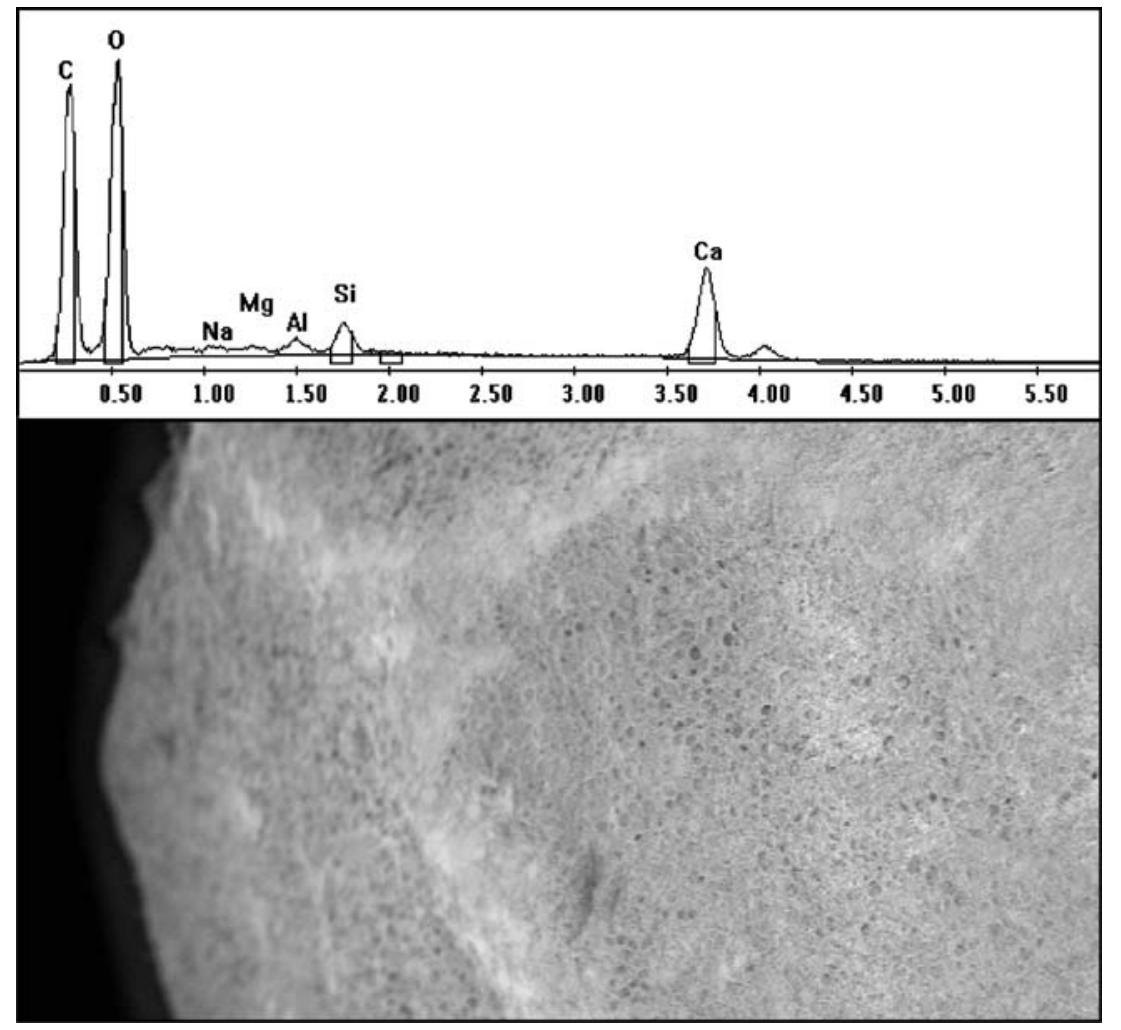


Fig. 4 IR spectra of fossil Celtis fruit ( $0.75 \mathrm{mg}$ analysed) and modern Celtis fruit $(0.75 \mathrm{mg}$ analysed). $\mathrm{Ar}$ aragonite, $\mathrm{Ca}$ calcite, $O M$ organic matter, $Q$ quartz

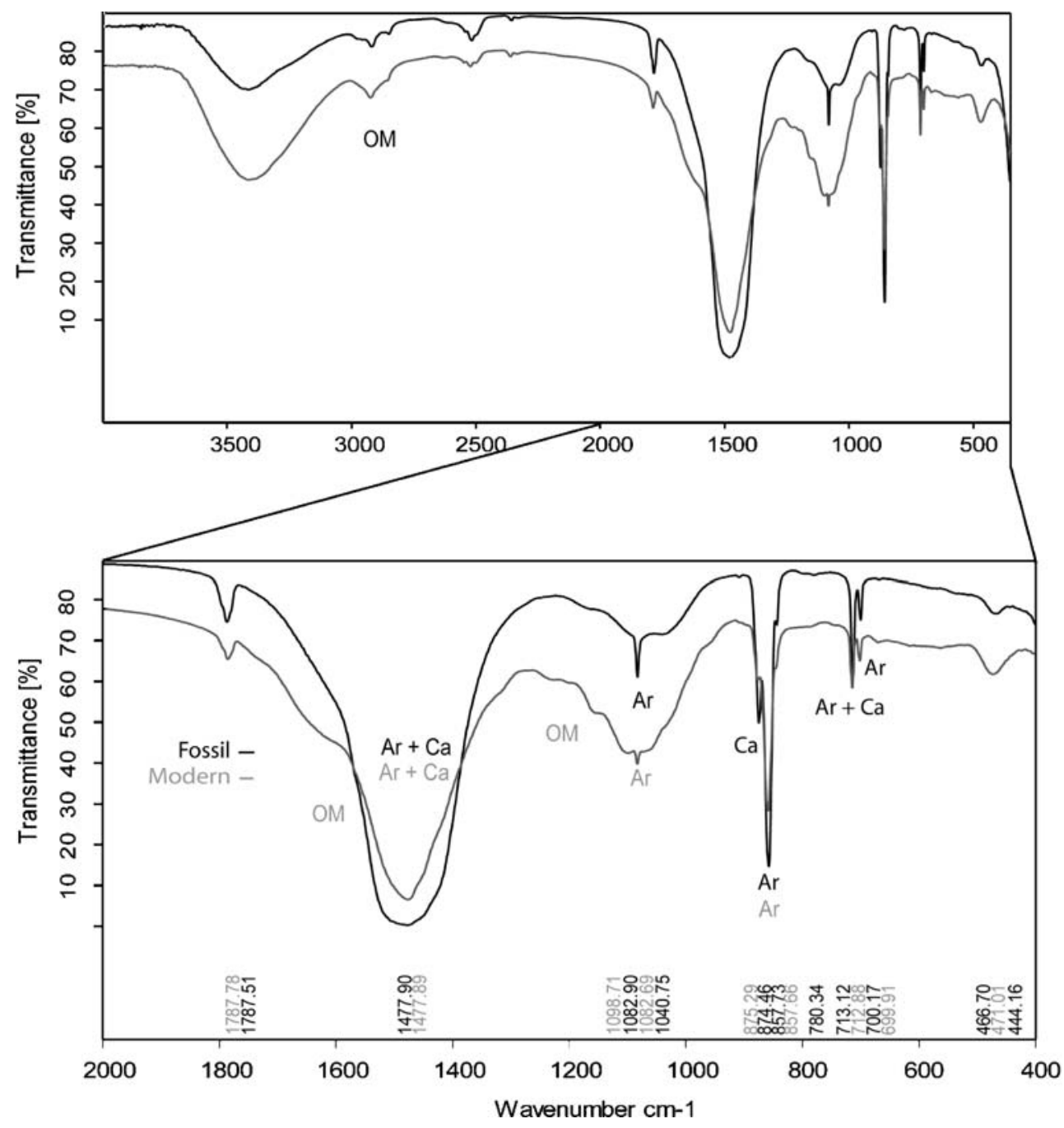

No major difference has been observed between the four analyses on fossil Lycopsis. Oxygen and silica are the most represented elements in the spectra (Fig. 5). Carbon and calcium are also present but in lower proportions.

b. Modern Lycopsis-type

Measurement spots on the modern Lycopsis coat section have been indicated in the ESEM image. The A measurement was done on the external epidermis and $\mathrm{B}$ and $\mathrm{C}$ on internal structures.

The three EDX spectra (Fig. 6) of the modern Lycopsis fruit section show the prevalence of carbon and oxygen. In the epidermis, the amount of silica is significant. This A measurement suggests that silica has impregnated the surficial layer of the living fruits of this taxon, but not the internal tissues.

\section{FTIR analysis}

\section{a. Fossil Lycopsis-type}

The infrared spectrum (Fig. 7) shows that fossil Lycopsis fruit contains predominantly biogenic, amorphous silica 
Fig. 5 Fossil Lycopsis fruit coat section with corresponding EDX measurements

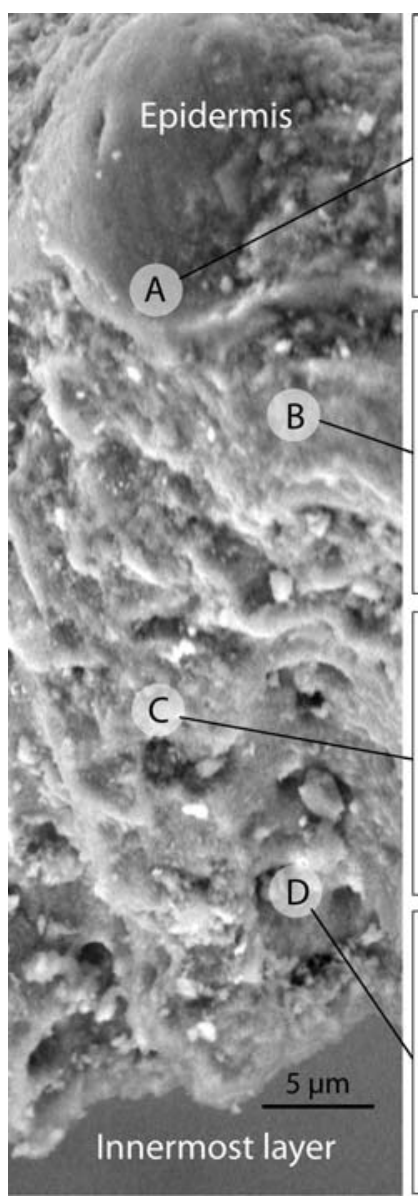

(opal: $79 \%$ ) with a low calcite content (4.5\%) and organic matter traces.

\section{b. Modern Lycopsis-type}

The infrared spectrum of modern Lycopsis (Fig. 7) is dominated by organic matter, along with amorphous silica, as indicated by the weak absorption bands at $800 \mathrm{~cm}^{-1}$ (diagnostic of Si-O-Si bond), 1,100 $\mathrm{cm}^{-1}$ (Si-O bond) and $960 \mathrm{~cm}^{-1}$ (Si-OH), which are typical for amorphous biogenic silica.

The coat composition of the Lycopsis specimens indicates that both modern and fossil fruits are biomineralised. The calcite content $(4.5 \%)$ of the fossil specimen is very low. Amorphous silica is the main mineral component in both modern and fossil specimen, but their infrared spectra exhibit two important differences:

- the $800 \mathrm{~cm}^{-1}$ band, which corresponds to an intertetrahedral (Si-O-Si) bending vibration mode (Lecomte, 1949), is stronger in the fossil Lycopsis than in the modern.

- the $960 \mathrm{~cm}^{-1}$ band, which corresponds to a Si-OH vibration mode (Moenke, 1974), is rather intense in the modern fruit, but is lacking in the fossil. This difference in the molecular structure of modern and
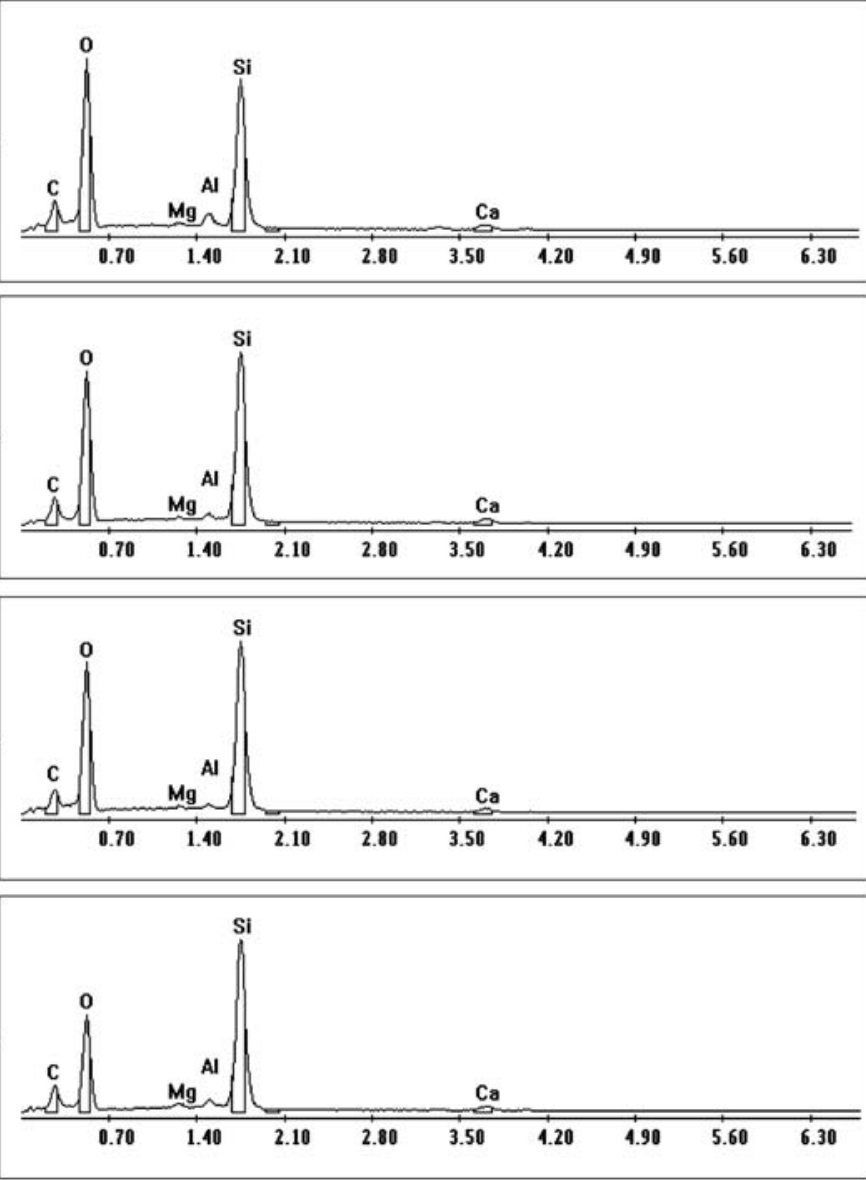

fossil biogenic silica was attributed to diagenesis $(\mathrm{OH}$ loss) by Fröhlich (1989) and is also observed in siliceous animals (sponge spicules) and algae (diatoms; GendronBadou et al. 2003).

\section{Buglossoides-type (Boraginaceae)}

Buglossoides sp. L. belongs to the same family (Boraginaceae) as Lycopsis sp. L. No EDX analysis was performed for this taxon and specimens were directly studied in FTIR.

\section{FTIR analysis}

\section{a. Fossil Buglossoides-type}

The infrared spectrum of fossil Buglossoides (Fig. 8) shows two main minerals: calcite $(47 \%)$ and biogenic amorphous silica $(20 \%)$.

\section{b. Modern Buglossoides-type}

In the infrared spectrum of modern Buglossoides (Fig. 8), biogenic hydroxylated $\left(960 \mathrm{~cm}^{-1}\right)$ silica $(26 \%)$ and calcite $(38 \%)$ are the main components.

The Buglossoides coat composition shows that this taxon is biomineralised with mixed calcite and biogenic silica. 
Fig. 6 Modern Lycopsis fruit coat section and corresponding EDX measurements

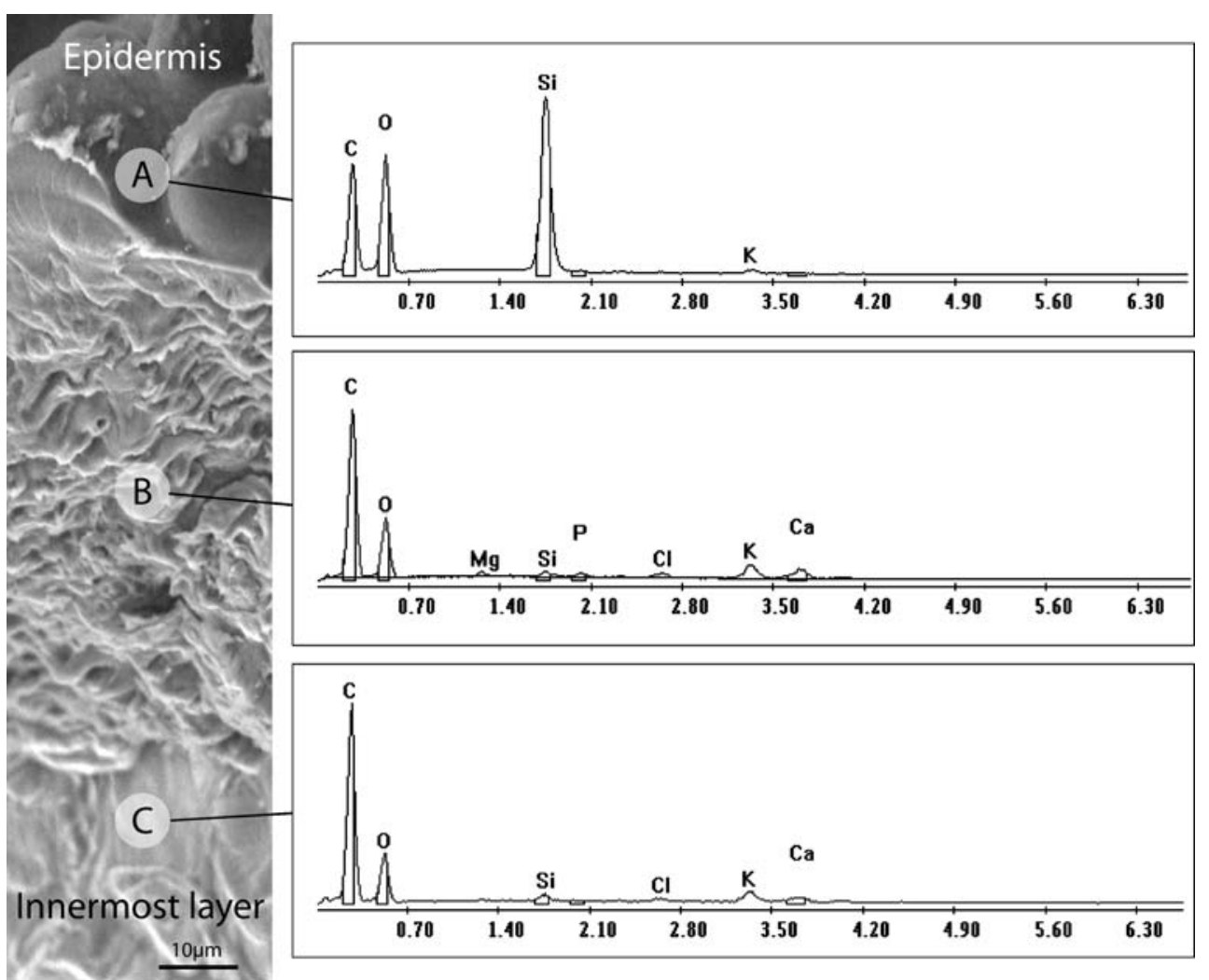

The lack of the $960 \mathrm{~cm}^{-1}$ band ( $\mathrm{Si}-\mathrm{OH}$ bond) in the fossil specimen is presumed to be due to diagenesis. The weak absorption bands at 566 and $605 \mathrm{~cm}^{-1}$ in the fossil specimen are typical of phosphate minerals (apatite structure).

\section{Discussion}

Fruit compositions

Celtis and Buglossoides fruits are known to be mineralised, specifically by biogenic carbonates (Yanovsky et al. 1932; Retallack 1990; Cowan et al. 1997; Wang et al. 1997; Jahren et al. 1998, 2001 for Celtis; Seibert 1978; Pustovoytov et al. 2004; Pustovoytov and Riehl 2006 for Buglossoides). Our analyses confirm the prevalence of carbonates in the fruit walls of both fossil and modern specimens. The Celtis modern fruits we studied are mostly composed of aragonite, as is expected for modern material (Cowan et al. 1997; Wang et al. 1997; Jahren et al. 1998). Fruit endocarps of Celtis are formed of a silica framework associated with aragonite deposits, even though silica opal structures may be lacking. In Celtis fruits, carbonate structure changes significantly between the modern and fossil specimens. The aragonite is replaced by calcite which is prevalent $(79 \%)$ in the fossil specimen, suggesting that the metastable aragonite from the endocarp walls is progressively recrystallised in calcite.

As for Celtis endocarps, carbonates and opal are involved in the mineralisation of the coat of Buglossoides fruits, but for this taxon, there is no significant modification of the carbonate content between modern and fossil specimens. Analyses indicate the prevalence of calcite in both fossil and modern fruits. Significant quantities of biogenic silica are also present in both samples. The three-dimensional organisation of silica in modern Buglossoides is characterised by the presence of $\mathrm{Si}-\mathrm{O}-\mathrm{Si}$ bonds $\left(800 \mathrm{~cm}^{-1}\right)$ with silanol groups $(\mathrm{Si}-\mathrm{O}-\mathrm{H})$ that are not present in the fossil sample. Such a molecular framework is characteristic of hydroxylated amorphous silica and is not linked with proteins. Our analyses indicate that calcite is present in Lycopsis fruits, but with a large amount of biogenic silica in both fossil and modern samples. This silica opal is associated with organic matter (probably proteins) in the coat of the modern fruits, while in fossils a three-dimensional reorganisation is observed, with the presence of a Si-O-Si framework. The difference in silica opal organisation between modern Lycopsis (Si-O-Protein) and Buglossoides (Si-O-H) is probably due to the origin of the material. The Lycopsis fruits were collected by one of the authors during fieldwork in Transcaucasia a few years ago, mixing young and mature fruits. The Buglossoides fruits are from old collections (more 
Fig. 7 IR spectra of fossil Lycopsis fruit $(0.75 \mathrm{mg}$ analysed) and modern Lycopsis fruit $(0.36 \mathrm{mg}$ analysed). $O p$ opal, $C a$ calcite, $O M$ organic matter

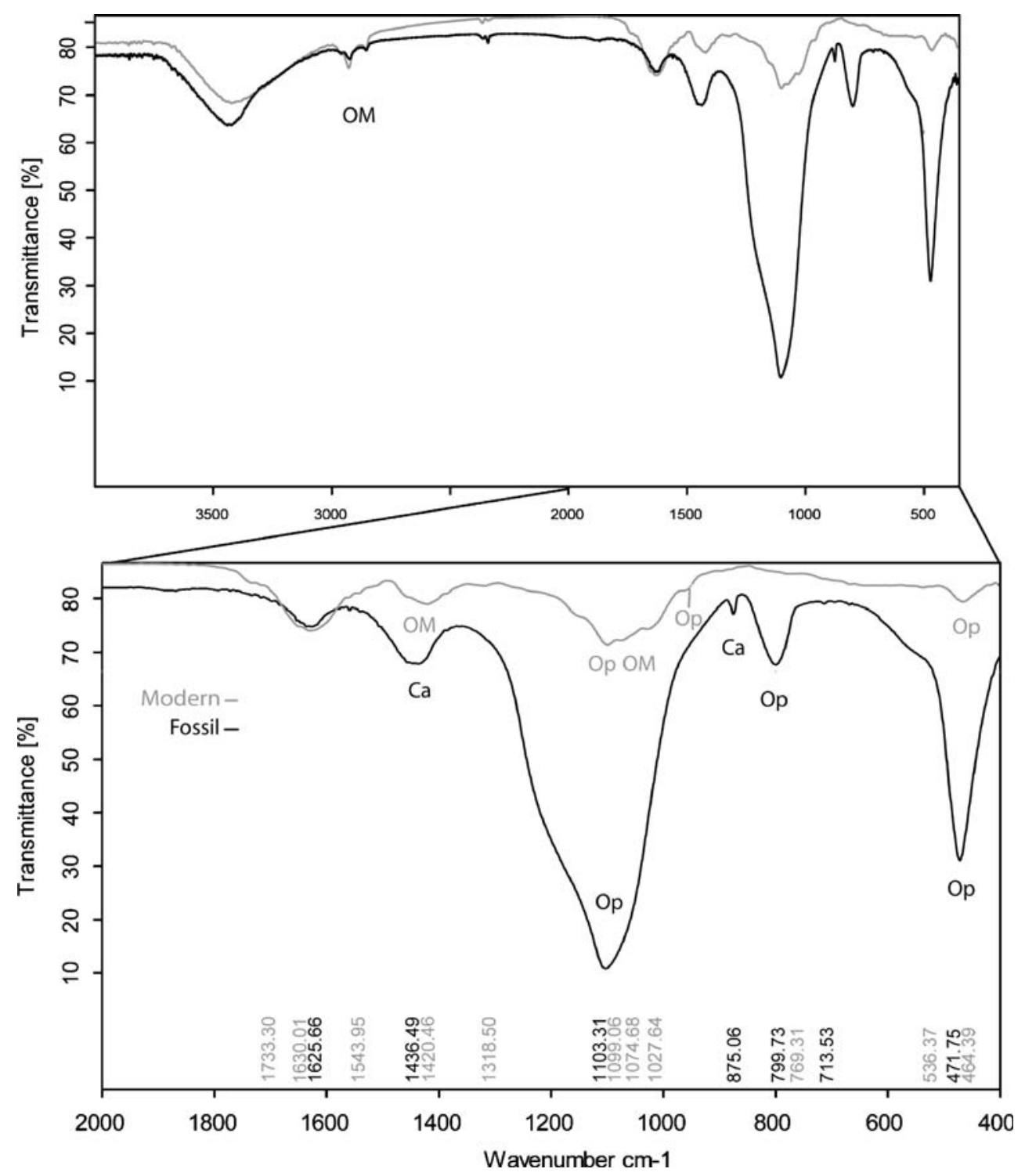

than one century) in the Herbarium and correspond to mature, very dry fruits.

\section{Post-depositional transformations}

A loss of organic matter is a feature observed on the three taxa. During fossilisation, the organic matter is destroyed and the inorganic part is restructured. For Celtis fruits, aragonite recorded in the modern samples is replaced by calcite (more stable carbonate) in the fossil sample. The replacement of aragonite by calcite is well known as a diagenetic process (Kunzler and Goodell 1970; Carlson 1983; Peric et al. 1996; Berndt and Seyfried 1999; Zhaodong et al., 2008) because aragonite is less stable than calcite in the conditions that prevailed at Earth's surface. However this might require a long period of time because previous studies of Holocene material have shown that aragonite predominates in some archaeological fruits of Celtis (Wang et al. 1997). The difference observed between these fossil carpo-remains and those we studied is probably due to the age of the Dmanisi fossils $(1.7 \mathrm{Ma})$, which are older and have presumably undergone more significant diagenesis. For Buglossoides and Lycopsis fruits, organic matter disappears and the silica opal is stabilised. The bonds between $\mathrm{Si}-\mathrm{O}$ and organic molecules and between $\mathrm{Si}$ and $\mathrm{OH}$ disappear and a new three-dimensional Si-O-Si framework is generated during fossilisation (GendronBadou et al. 2003). This confers to the fossil, a condensed mineralogical structure that becomes more stable and thicker. This silica reorganisation leads to a better resistance to dissolution (Fröhlich 1989). Such transformation has been previously observed in very old diatoms from Miocene 
Fig. 8 IR spectra of fossil Buglossoides fruit $(0.75 \mathrm{mg}$ analysed) and modern Buglossoides fruit $(0.75 \mathrm{mg}$ analysed). $\mathrm{Op}$ opal, $\mathrm{Ca}$ $P h$ phosphate calcite, $O M$ organic matter,

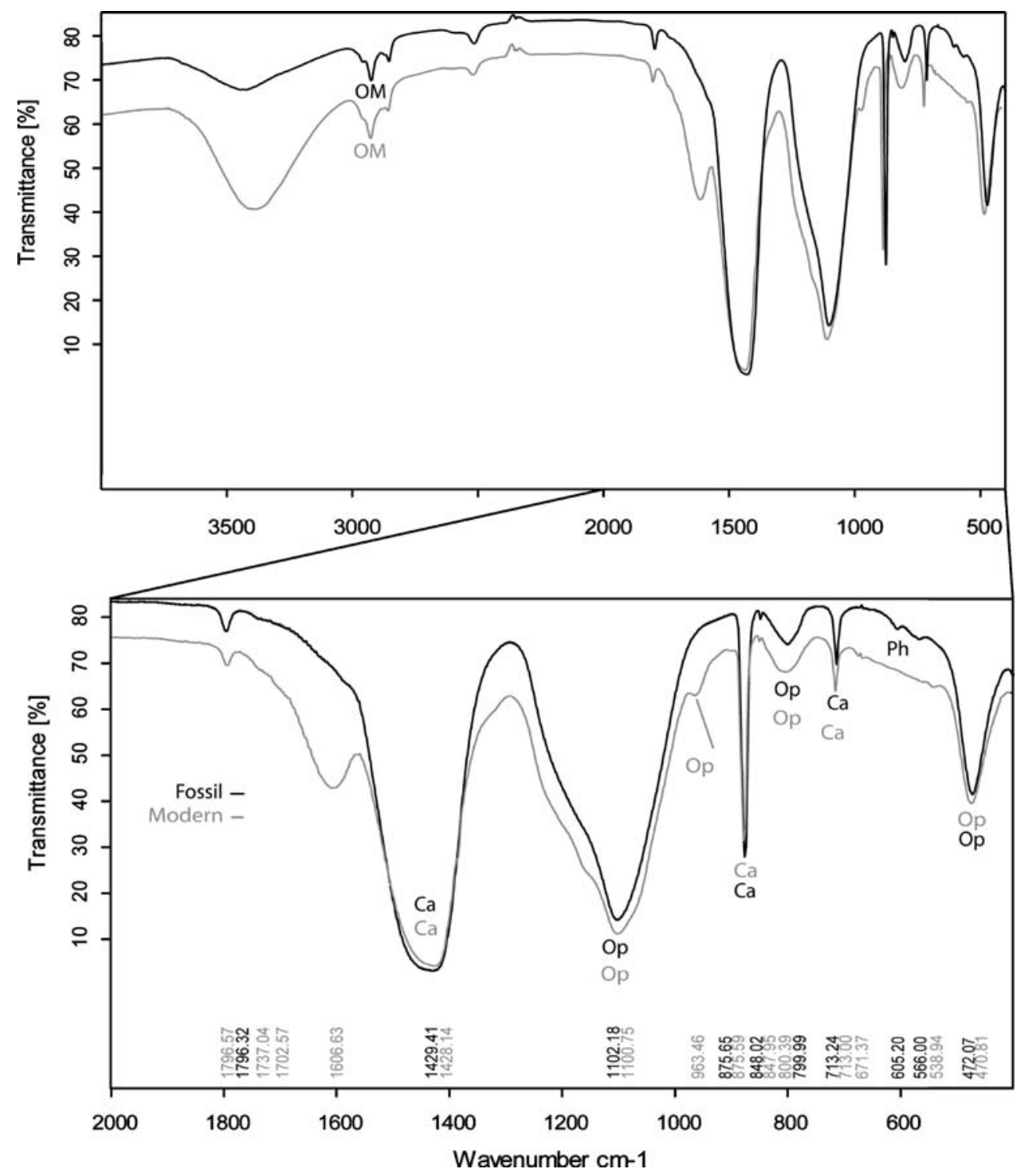

Preservation features and archaeological implications

deposits (Gendron-Badou et al. 2003). For the first time, we observed the effects of diagenesis on biogenic opal in fossil fruits remains.

The fossil remains of Buglossoides are shown to contain some phosphate minerals with a typical apatite structure. This can be interpreted as infiltration by a calcium phosphate solution, followed by precipitation within the fruits, representing a phosphatisation process (Green 1979; McCobb et al. 2001, 2003). The Buglossoides fruit analysis suggests a double mineralisation: biomineralisation and weak phosphatisation. The phosphatisation process depends upon the structural features of the tissues (McCobb et al. 2001, 2003). Phosphatisation can occur in soft tissues (Briggs and Wilby 1996), but can also affect robust propagules such as Prunus or Rubus endocarps (McCobb et al. 2001). Our analysis confirms that biomineralisation of Buglossoides fruits does not prevent secondary mineralisation by calcium phosphate.
All of the fruit morphotypes studied in this work have been primarily mineralised through biomineralisation by the living plant. Such fruits naturally have a higher probability of being represented in carpological assemblages. They do not have to be charred to survive, but can also be well represented in assemblages from burned structures. As suggested by our results, the diagenetic history of these remains reinforces their preservation potential because mineral structures are particularly stable (calcite and condensed silica opal) in fossil specimens. Comprising mainly mineral components, they can be preserved in various kinds of deposits, although calcium carbonate is unstable under low-pH conditions and would not be predicted to survive in acidic deposits. The present study illustrates how this kind of carpo-remains can be preferentially preserved in some 
geological or archaeological deposits because of their natural mineralised components.

As mentioned previously, fossil mineralised botanical remains exhibit a fresh appearance which makes their contemporaneity with other archaeological finds questionable (Green 1979). For the Dmanisi site, the botanical remains are from a very well-known stratigraphical context. They are mostly recovered in the upper part of the stratigraphy corresponding to the archaeological layers. In this part of the sequence, remains are sometimes embedded in the laminated calcrete (cf 'Materials' section). Moreover, several fruits come from the lower part of the stratigraphy (pipes) located under the carbonate horizon. These stratigraphical locations restrict post-depositional disturbance because this laminated carbonate zone appears to not have been penetrated before very recent times (Gabunia et al. 2000a). The comparison between the modern and the fossil samples that we performed can be considered as a good indication of the influence of the ageing process on the mineral structure. The results suggest a very advanced state of diagenesis for the fossil carbonates (not observed in Holocene samples) and for fossil silica opal (previously observed in Miocene material). The timing of such alteration processes are in agreement with the age of the Dmanisi assemblage.

Because of the highlighted taphonomical bias, these fruit remain assemblages cannot give an accurate picture of the whole flora that lived on the site. However, they can be used profitably for complementing environmental interpretations because they can be recovered in sedimentary contexts where other botanical remains have disappeared (e.g., where there has been no fire and organic matter is rare). Carpo-remains which were mineralised by phosphatisation processes show variable degrees of preservation (Green 1979; McCobb et al. 2001; Matterne 2001). In contrast, biomineralisation by the living plant permits much better preservation of the coat ornamentation, as has also been observed for algae and animals (Gendron-Badou et al. 2003). For a site of that age, and taking into account the taphonomical bias, the palaeobotanical assemblage of Dmanisi is a good indicator of the plants which occupied the site during the period when stratum B was deposited (Messager et al. 2008). The recognised taxa indicate local open vegetation with rather dry climatic conditions. A pioneer and xeric meadow vegetation probably grew in the Dmanisi area during the drought event recorded by other proxies in the upper part of the stratigraphy (Gabunia et al. 2000b; Messager 2006).

\section{Conclusion}

EDX and FTIR analyses carried out on modern and fossil fruits revealed three different styles of mineralisation in the taxa examined. They are all biomineralised with amorphous silica or/and carbonates, but not in the same proportions. Silica is over-represented in Lycopsis and Buglossoides fruits. Celtis and Buglossoides fruit walls are mostly composed of carbonates, but Lycopsis contains very few. Carbonates are present in two different forms, aragonite and calcite in the specimens of Celtis fruits and calcite only in Buglossoides. These biological mineralisations confer on the fruits a preservational advantage, although other, postdepositional, processes have certainly occurred during fossilisation. Although fresh and fossil carpo-remains are not at the same stage of post-depositional evolution, this does not limit their preservation potential because certain mineral structures are relatively stable in fossil specimens. The preservation of mineralised botanical remains in sediments depends upon other factors, such as environmental and geochemical processes, that need to be investigated. However, it can be assumed that a significant taphonomical bias exists due to the biomineralised nature of these botanical remains. This exceptional preservation permits the recovery of fruit remains from the mineral context of a site as old as Dmanisi. Taking into account the taphonomic bias, the carpological assemblage helps to reconstruct the local ecological conditions.

Acknowledgments This study was prepared in collaboration with the Georgian National Museum, the French Museum of Natural History (MNHN) and the René Ginouvès Institute for Archaeology and Anthropology (MAE). We wish to express our gratefulness to Lucy Mc Cobb for her comments on the paper and the English editing which significantly helped to improve the manuscript. This research was completed during a postdoctoral project coordinated by Stéphanie Thiébault and supported by the 'Ile de France regional council'. We thank Dorian Q. Fuller and two anonymous reviewers for their constructive suggestions, which greatly improved our paper.

\section{References}

Berndt ME, Seyfried WE (1999) Rates of aragonite conversion to calcite in dilute aqueous fluids at 50 to $100^{\circ} \mathrm{C}$ : experimental calibration using Ca-isotope attenuation. Geochim Cosmochim Acta 63:373-381

Briggs DEG, Wilby PR (1996) The role of the calcium carbonate calcium phosphate switch in the mineralization of soft-bodied fossils. J Geol Soc London 153:665-668

Carlson WD (1983) The polymorphs of $\mathrm{CaCO} 3$ and the aragonitecalcite transformation. In: Reeder RJ (ed) Carbonates: Mineralogy and Chemistry, Mineral. Soc. Am., Rev. Mineral 11:191-225

Cowan MR, Gabel ML, Jahren AH, Tieszen LL (1997) Growth and biomineralization of Celtis occidentalis (Ulmaceae) pericarps. Am Midl Nat 137(2):266-273

Deniaux B (2002) La microscopie électronique à Balayage environnementale. In: Miskovsky JC (ed) Géologie de la Préhistoire Géopré-Press Universitaire de Perpignan, pp 589-599

Dzaparidze V, Bosinski G, Bugianisvili T, Gabunia L, Justus A, Klopotovskaja N, Kvavadze E, Lordkipanidze D, Maisuradze G, Mgeladze N, Nioradze M, Pavlenishvili E, Schmincke H-U, Sologasvili D, Tusabramisvili D, Tvalcrelidze M, Vekua A 
(1989) Der alfipaläolithische Fundplatz Dmanisi in Georgian (Kaukasus). Jahrbuch des Römisch-Germanischen Zentralmuseums Mainz 36:67-116

Ferring CR, Lordkipanidze D, Berna F, Ohms O (2008) Geology and formation processes at Dmanisi in the Georgian Caucasus. Abstracts of the 73rd Annual Meeting, Society for American Archaeology, pp 195

Fröhlich F (1989) Deep-sea biogenic silica: new structural and analytical data from infrared analysis-geological implications. Terra Nova 1:267-273

Fröhlich F, Gendron-Badou A (2002) La spectroscopie infrarouge, un outil polyvalent. In: Miskovsky J-C (ed) Géologie de la Préhistoire, AEEGP, éditeur. Paris. pp 662-677

Gabunia L, Vekua A, Lordkipanidze D, Swisher CC III, Ferring R, Justus A, Nioradze M, Tvalcrelidze M, Anton SC, Bosinski G, Jöris O, de Lumley MA, Majsuradze G, Mouskhelishvili A (2000a) Earliest Pleistocene hominid cranial remains from Dmanisi, Republic of Georgia: taxonomy, geological setting, and age. Science 288:1019-1025

Gabunia L, Vekua A, Lordkipanidze D (2000b) The environmental contexts of early human occupation of Georgia (Transcaucasia). J Hum Evol 38:785-802

Gendron-Badou A, Coradin T, Maquet J, Frölich F, Livage J (2003) Spectroscopic characterization of biogenic silica. J Non-Cryst Solids 316:331-337

Green FJ (1979) Phosphatic mineralization of seeds from archaeological sites. J Archaeol Sci 6:279-284

Jahren AH, Gabel ML, Amundson R (1998) Biomineralization in seeds: developmental trends in isotopic signatures of hackberry. Palaeogeogr Palaeoclimatol Palaeoecol 138:259-269

Jahren AH, Amundson R, Kendall C, Wigand P (2001) Paleoclimatic reconstruction using the correlation in $\delta 18 \mathrm{O}$ of hackberry carbonate and environmental water, North America. Quatern Res 56(2):252-263

Kunzler RH, Goodell HG (1970) The aragonite-calcite transformation: a problem in the kinetics of a solid-solid reaction. Am J Sci 269:360-391

Lecomte J (1949) Le rayonnement infrarouge. Gauthier-Villard, Paris

Lordkipanidze D, Jashashvili T, Vekua A, Ponce de León MS, Zollikofer CE, Rightmire GP, Pontzer H, Ferring R, Oms O, Tappen M, Bukhsianidze M, Agusti J, Kahlke R, Kiladze G, Martinez-Navarro B, Mouskhelishvili A, Nioradze M, Rook L (2007) Postcranial evidence from early Homo from Dmanisi, Georgia. Nature 449:305-310

Matterne V (2001) Agriculture et alimentation végétale durant l'âge du Fer et l'époque gallo-romaine en France septentrionale. M. Mergoil Edition, Montagnac

McCobb LME, Briggs DEG, Evershed RP, Hall AR, Hall RA (2001) Preservation of fossil seeds from a 10th century AD cess pit at Coppergate, York. J Archaeol Sci 28:929-940
McCobb LME, Briggs DEG, Carruthers WJ, Evershed RP (2003) Phosphatisation of seeds and roots in a Late Bronze Age deposit at Potterne, Wiltshire, UK. J Archaeol Sci 30:1269-1281

Messager E, (2006) Apports des études paléobotaniques à la reconstitution paleoenvironnementale du site de Dmanissi et de sa région (Géorgie). Ph.D. Thesis, Museum National d'Histoire Naturelle, Paris.

Messager E, Lordkipanidze D, Ferring CR, Deniaux B (2008) Fossil fruit identification by SEM investigations, a tool for palaeoenvironmental reconstruction of Dmanisi site, Georgia. J Archaeol Sci 35(10):2715-2725

Moenke HHW (1974) The infrared spectra of minerals. In: EVC Farmer (ed) Mineralogical Society Monograph, London, pp. 365

Peric J, Vucak M, Krstulovic R, Brecevic LJ, Kralj D (1996) Phase transformation of calcium carbonate polymorphs. Thermochim acta $277: 175-186$

Pichard C, Fröhlich F (1986) Analyses infrarouges quantitatives des sédiments. Exemple du dosage du quartz et de la calcite. Revue de l'Institut Français du Pétrole 41(6):809-819

Pustovoytov K, Riehl S (2006) Suitability of biogenic carbonate of Lithospermum fruits for 14C dating. Quatern Res 65(3):508-518

Pustovoytov K, Riehl S, Mittmann S (2004) Radiocarbon age of carbonate in fruits of Lithospermum from the early Bronze Age settlement of Hirbet ez-Zeraqon (Jordan). Veg Hist Archaeobot 13:207-212

Retallack G (1990) Soils of the past, an introduction to Paleopedology. Blackwell publishing, London

Seibert J (1978) Fruchtanatomische Untersuchungen an Lithospermeae (Boraginaceae). Dissertationes Botanicae 44:1-207

van Zeist W, Buitenhuis H (1983) Palaeobotanical studies of Neolithic Erbaba, Turkey. Anatolica 10:47-89

van Zeist W, de Roller GJ (1995) Plant remains from Asikli Hoyuk, a pre-pottery Neolithic site in central Anatolia. Veg Hist Archaeobot 4:179-185

Vekua A, Lordkipanidze D, Rightmire GP, Agusti J, Ferring R, Maisuradze G, Zollikofer C (2002) A new skull of early Homo from Dmanisi, Georgia. Science 297:85-89

Wang Y, Jahren AH, Amundson RG (1997) Potential for ${ }^{14} \mathrm{C}$ dating of biogenic carbonate in hackberry (Celtis) endocarps. Quatern Res 47:337-343

Wilby PR, Briggs DEG (1997) Taxonomic trends in the resolution of detail preserved in fossil phosphatized soft tissues. Geobios 20:493-502

Yanovsky E, Nelson EK, Kingsbury RM (1932) Berries rich in calcium. Science 75:565-566

Zhaodong N, Xiangna C, Qianqian Y, Xiuzhen W, Zuoyi S, Wanguo H (2008) Structure transition from aragonite to vaterite and calcite by the assistance of SDBS. J Colloid Interface Sci 325:331-336 